\title{
MASYARAKAT EKONOMI ASEAN (MEA) SETELAH TIGA TAHUN PENGIMPLEMENTASIAN DI INDONESIA
}

\author{
Gita Paramita Agustin \\ *Program Studi Akuntansi, Fakultas Ekonomi dan Bisnis \\ Universitas Peradaban Bumiayu \\ *gitaaparamita@gmail.com
}

\begin{abstract}
The ASEAN Economic Community (AEC) is a community of ASEAN countries having a vision and mission to further enhance the welfare of ASEAN countries. The AEC makes the boundaries that were more complicated and difficult to run easier and there are almost no restrictions at all in terms of the economy. There are several advantages and disadvantages with the enactment of the AEC in Indonesia. The AEC is expected to further improve the economy in Indonesia. The level of export imports, poverty rates and the number of unemployed and the level of income per capita and gross domestic product are indicators in measuring the economic development in a country. To find out the success of the AEC which has been running for 3 years, this study will compare these indicators before and after the enactment of the AEC in Indonesia.
\end{abstract}

Keywords: ASEAN Economic Community (AEC), import exports, poverty rates, unemployment, per capita income and gross domestic product.

\section{A. PENDAHULUAN}

\begin{tabular}{cllr}
\multicolumn{2}{c}{ Masyarakat } & Ekonomi & ASEAN \\
(MEA) atau Asean Economic
\end{tabular}

Community (AEC) adalah suatu realisasi integrasi ekonomi yang terkandung di dalam visi ASEAN 2020 (Naukoko, 2017). Awal pelaksanaan MEA pada 31 Desember 2015 membawa beberapa dampak baik bagi kebijakan pemerintah dan perekonomian secara luas di Indonesia. MEA sendiri awalnya disepakati akan dilaksanakan pada tahun 2020 nanti, namun dipercepat sehingga pelaksanaannya di akhir tahun 2015. Indonesia merupakan salah satu dari beberapa negara yang tergabung dalam organisasi Asia Tenggara atau yang biasa kita sebut dengan ASEAN (Association of Southeast Asian Nations). Tujuan utama dari pembentukan MEA adalah untuk mengembangkan perekonomian negara-negara ASEAN sehingga dapat meningkatkan kesejahteraan dan persaingan yang kompetitif yang saling terintegrasi satu sama lain antar negara-negara Asean (Syaifullah dan Malik, 2017). ASEAN sudah memasuki usia yang cukup matang yaitu 51 tahun (1967-2018) yang apabila disamakan dengan usia manusia merupakan usia yang sangat produktif. Namun permasalahan yang selalu membayangi pada negara-negara ASEAN kelompok menengah seperti Indonesia, Malaysia, Thailand, dan Filipina yaitu kemiskinan.

Menurut Pratiwi dan Mahmudah (2013) hal-hal yang diharapkan dari MEA antara lain : 1) Pasar tunggal dan kesatuan bisnis produksi 2) Kawasan ekonomi yang berdaya saing 3) Pertumbuhan ekonomi yang merata 4) Meningkatkan kemampuan untuk berintegrasi dengan perekonomian global. Ketentuan tersebut mengakibatkan adanya perdagangan barang, jasa, modal dan investasi 
akan bergerak bebas seakan tidak ada halangan secara geografis. Terdapat dampak positif dan negatif dari pelaksanaan MEA di Indonesia sejak tahun 2015. Dampak positif dari MEA adalah memacu pertumbuhan investasi dari dalam maupun luar negeri. Pertumbuhan investasi akan berpotensi meningkatkan jumlah lapangan kerja dalam negeri. Sehingga akan mengurangi jumlah pengangguran dan meningkatkan kesejahteraan perkapita. Selain itu masyarakat Indonesia juga dapat mencari pekerjaan di luar negeri dengan aturan yang lebih mudah (Pratiwi dan Mahmudah, 2013).

Dampak negatifnya adalah dengan adanya pasar barang dan jasa secara bebas di negara-negara ASEAN berdampak pada ketenagakerjaan, yaitu persaingan tenaga kerja semakin ketat karena tenaga kerja asing akan masuk ke Indonesia. Tenaga kerja lokal harus dapat bersaing secara kompetitif dengan tenaga kerja asing. Padahal tingkat pendidikan dan keahlian tenaga kerja lokal masih agak rendah apabila dibandingkan tenaga kerja asing. Hal inilah yang akan menambah rumit masalah ketenagakerjaan di Indonesia.

Berlakunya MEA membuat perusahaan-perusahaan dituntut untuk menghadapi suatu tantangan merebut peluang pasar dalam lingkungan bisnis yang semakin kompetitif, sehingga menciptakan persaingan yang ketat antar perusahaan baik di dalam negeri maupun di luar negeri (Suryandani, 2018). Peran pemerintah untuk membuat regulasi untuk mengatur arus perdagangan perlahan akan menghilang dan digantikan dengan aturan pasar. Bagi negara berkembang seperti Indonesia, hal ini merupakan kekhawatiran yang serius karena adanya daya saing produk yang rendah untuk bisa minimal bertahan atau malah gagal karena desakan dari investasi asing.
Pelaksanaan MEA dari akhir tahun 2015 sampai saat ini memasuki tahun keempat. Tiga tahun sudah Indonesia bergelut dengan adanya peluang yang ditimbulkan dari dampak positif dan tantangan yang ditimbulkan dari dampak negatif yang dihadapi setelah dimulainya MEA. Setelah tiga tahun pengimplementasian MEA apakah Indonesia sudah mendapatkan tujuan yang diharapkan dari awal yaitu pertumbuhan ekonomi dan kesejahteraan masyarakat yang meningkat atau malah sebaliknya karena ketidaksiapan tenaga kerja lokal sehingga gagal bersaing dengan tenaga kerja asing yang masuk ke Indonesia. Sehingga menimbulkan penurunan kesejahteraan masyrakat.

Berdasarkan penjelasan diatas, peneliti ingin mengungkapkan analisis tingkat keberhasilan MEA yang telah dilakukan di Indonesia dari akhir tahun 2015 sampai sekarang.

\section{Rumusan Masalah}

1. Bagaimana tingkat ekspor impor sebelum dan sessudah diberlakukan MEA 2015 di Indonesia.

2. Bagaimana jumlah penduduk miskin dan tingkat pengangguran sebelum dan sesudah diberlakukan MEA 2015 di Indonesia.

3. Bagaimana tingkat pendapatan perkapita dan produk domestik bruto sebelum dan sesudah diberlakukan MEA 2015 di Indonesia.

\section{Tujuan Penelitian}

1. Untuk menjelaskan, menggambarkan, dan mengkaji bagaimana tingkat ekspor impor sebelum dan sesudah diberlakukan MEA 2015 di Indonesia.

2. Untuk menjelaskan, menggambarkan, dan mengkaji bagaimana jumlah penduduk miskin dan tingkat pengangguran sebelum dan sesudah 
diberlakukan MEA 2015 di Indonesia.

3. Untuk menjelaskan, menggambarkan dan mengkaji bagaimana tingkat pendapatan perkapita dan produk domestik bruto sebelum dan sesudah diberlakukan MEA 2015 di Indonesia.

\section{Manfaat Penelitian}

1. Sebagai tambahan ilmu pengetahuan, wawasan, dan pembelajaran mengenai bagaimana keadaan perekonomian sebelum dan sesudah MEA 2015 di Indonesia

2. Sebagai tambahan ilmu pengetahuan, wawasan dan pembelajaran mengenai tingkat keberhasilan MEA 2015 setelah diberlakukan selama 3 tahun di Indonesia.

\section{B. TINJAUAN PUSTAKA}

\section{Masyarakat Ekonomi ASEAN (MEA)}

Suatu komunitas negara-negara ASEAN yang sangat luas dan tidak ada batasan-batasan wilayah dalam bidang perekonomian (Firdaus dan Hakim, 2013). Negara-negara yang tergabung dalam ASEAN dapat masuk bebas dalam persaingan pasar. Dikutip dari Indonesia raya news 2013 "Masyarakat Ekonomi ASEAN akan bebas dari berbagai hambatan, pengutamaan peningkatan konektivitas, pemanfaatan berbagai skema kerja sama baik intra-ASEAN maupun antara ASEAN dengan negara mitra khususnya mitra FTA, serta penguatan peran UKM dalam proses integrasi internal ASEAN maupun dengan negara mitra".

MEA merupakan suatu kesepakatan negara-negara ASEAN dalam rangka mewujudkan visi ASEAN 2020 yang telah disusun sejak tahun 1997 di Kualalumpur (Avianti, 2015). Terdapat 3 pilar komunitas ASEAN yang mana salah satunya yaitu ASEAN Economic Community (AEC) yang berfokus pada menjadikan negara-negara ASEAN sebagai kawasan perdagangan bebas barang, jasa investasi, tenaga kerja dan aliran modal.

Pasar regional bagi penduduk ASEAN akan terbentuk dengan adanya MEA yang memberikan kawasan perdagangan bebas bagi negara-negara ASEAN. Hal ini didukung dengan 4 karakteristik MEA sebagai berikut (Avianti, 2015) :

1. Single market and production base

Satu pasar dan basis produksi di ASEAN yang menyebabkan arus bebas barang, arus bebas jasa, arus bebas investasi, arus permodalan lebih bebas, arus bebas tenaga kerja terampil, serta pengembangan sektorsektor ekonomi di negara-negara ASEAN.

2. Competitive economic region

Persaingan ekonomi regional yang berkomptensi, adanya perlindungan akan konsumen, perlindungan Hak Kekayaan Intelektual, regulasi perpajakan yang tidak memberatkan, dan hal lain yang mendukung adanya persaingan ekonomi regional yang kompetitif dan adil bagi antar negara ASEAN.

3. Equitable economic development Pembangunan ekonomi yang seimbang dari sektor usaha kecil dan menengah (UKM) serta berupaya untuk mengurangi kesenjangan antar negara ASEAN dan dengan negaranegara lain di dunia.

4. Fully integrated region in the global economy

Kawasan ekonomi yang terintegrasi dengan perekonomian global, dimana negara-negara ASEAN diharapkan dapat meningkatkan jaringan suplai terhadap antar negara ASEAN dam negara-negara lain di dunia.

Karakteristik MEA ini akan mempengaruhi perekonomian suatu negara, baik di tingkat perdangangan seperti 
ekspor impor, persaingan tenaga kerja lokal dengan tenaga kerja asing dan nantinya akan berdampak pada kesejahteraan penduduk di suatu negara. Tingkat ekspor impor akan diukur setelah adanya MEA, apakah mengalami peningkatan atau justru mengalami penurunan. Tingkat kemiskinan dan jumlah pengangguran dapat dijadikan indikator untuk mengukur kesejahteraan suatu negara. Pendapatan perkapita dan produk domestik bruto juga dapat digunakan untuk mengetahui bagaimana perbedaan pertumbuhan perekonomian di Indonesia sebelum dan setelah adanya MEA.

\section{Ekspor Impor}

Ekspor adalah menjual barang dagangan dari dalam negeri ke luar negeri. Barang-barang yang diekspor biasanya barang-barang khas yang memang dihasilkan dan diproduksi di Indonesia. Misalnya kerajinan tangan, bahan pangan yang hanya ada di Indonesia. Ekspor dilakukan karena negara lain membutuhkan komoditas tersebut tetapi tidak dapat menghasilkan dan memproduksi sendiri. Ekspor sangat menguntungkan bagi pemerintah karena akan menghasilkan devisa yang akan masuk ke kas negara. Kas negara nantinya digunakan untuk pembangunan dan kesejahteraan rakyat. Diberlakukannya MEA diharapkan dapat meningkatkan tingkat ekspor karena adanya kemudahan regulasi untuk para pengusaha dalam melakukan ekspor.

Impor adalah membeli atau memasukkan barang dagangan dari luar negeri ke dalam negeri. Kebalikan dari kegiatan ekspor, impor dianggap kurang menguntungkan bagi pemerintah. Biasanya barang impor dijual dengan harga yang lebih murah daripada harga jual barang asli Indonesia. Hal inilah yang ditakutkan oleh pengusaha kecil dengan adanya MEA 2015. Karena MEA 2015 dianggap akan mematikan pengusaha kecil yang memproduksi barang sama yang ada di dalam negeri karena kalah saing dengan barang impor.

\section{Jumlah Penduduk Miskin dan Tingkat Pengangguran}

Tingkat kemiskinan dan jumlah pengangguran sangat penting untuk menunjukkan bagaimana tingkat perekonomian di suatu negara. Semakin banyak jumlah pengangguran menunjukkan bahwa masyarakat akan lebih kesulitan dalam melakukan kehidupan sehari-hari karena tidak memiliki pekerjaan. Hal ini akan menimbulkan peningkatan pada tingkat kemiskinan. Diberlakukannya MEA diharapkan akan mengurangi jumlah pengangguran dan menekan angka kemiskinan yang ada di Indonesia. Hal ini disebabkan adanya kemudahan regulasi antara negara-negara ASEAN tentang penerimaan tenaga kerja asing. Tenaga kerja Indonesia diharapkan mampu bersaing dan mendapatkan pekerjaan walaupun tidak di dalam sendiri.

\section{Pendapatan per Kapita dan Produk Domestik Bruto}

Pendapatan per kapita adalah pendapatan rata-rata penduduk di suatu negara. Pendapatan per kapita dihitung dari pendapatan nasional suatu negara dibagi dengan jumlah penduduk yang ada di negara tersebut. Sedangkan produk domestik bruto adalah nilai pasar semua barang dan jasa yang diproduksi oleh suatu negara pada periode tertentu. Produk domestik bruto merupakan salah satu metode yang digunakan untuk menghitung pendapatan nasional. Meningkatnya produk domestik bruto akan berbanding lurus dengan peningkatan pendapatan nasional. MEA 2015 diharapkan dapat memicu pengusaha dalam negeri untuk lebih meningkatkan dalam memproduksi barang dan jasa. 
Barang dan jasa ini dapat dijual di dalam negeri sendiri maupun dapat di ekspor ke luar negeri. Kelonggaran regulasi yang merupakan dampak MEA seyogyanya dapat dimanfaatkan oleh pengusaha untuk lebih giat lagi dalam memproduksi barang dan jasa. Peningkatan produk domestik bruto dapat dijadikan indikator bahwa pendapatan per kapita juga meningkat. Adanya peningkatan pendapatan per kapita dapat dijadikan patokan bahwa pemerintah telah berhasil memberlakukan MEA untuk peningkatan kesejahteraan masyarakat.

\section{METODE PENELITIAN}

Penelitian ini dilakukan dengan menggunakan pendekatan kualitatif deskriptif. Pendekatan kualitatif dilakukan dengan cara dokumentasi yaitu data yang digunakan adalah tinjauan pustaka yang diperoleh dari sumber tertulis maupun digital untuk memahami dan memaparkan bagaimana tingkat keberhasilan MEA setelah berjalan selama 3 tahun. Selain itu digunakan uji perbandingan data antara periode sebelum MEA dan setelah dilaksanakan MEA.

Analisis data yang dilakukan terdiri atas deskripsi dan analisis isi. Deskripsi peneliti akan menjelaskan datadata atau hasil penelitian melalui teknik pengumpulan data. Data yang terkumpul kemudian akan dianalisis dengan analisis kualitatif. Data yang diperoleh dari sumber-sumber terpercaya seperti Badan Pusat Statistik (BPS) untuk memperoleh data yang dibutuhkan. Data yang akan digunakan adalah data ekspor impor yang dilakukan sebelum dan setelah MEA, tingkat kemiskinan dan jumlah pengangguran sebelum dan setelah MEA, pendapatan perkapita dan pendapatan domestik bruto sebelum dan setelah MEA.

\section{HASIL DAN PEMBAHASAN}

\section{Ekspor Impor}

Data ekspor diambil dari tahun 2013-2018 dari website resmi Badan Pusat Statistik (BPS). 2013-2015 merupakan 3 tahun sebelum diberlakukan MEA di Indonesia. Sedangkan 20162018 merupakan periode 3 tahun setelah diberlakukan MEA di Indonesia. Data yang terdapat dalam tabel dibawah menggunakan satuan Juta US dolar.

Tabel 1. Data Ekspor di Indonesia

\begin{tabular}{|c|c|c|c|c|}
\hline \multicolumn{2}{|c|}{ Periode } & Migas & $\begin{array}{l}\text { Non } \\
\text { Migas }\end{array}$ & $\begin{array}{l}\text { Total } \\
\text { Ekspor }\end{array}$ \\
\hline \multirow{3}{*}{$\begin{array}{l}\text { Sebelum } \\
\text { MEA }\end{array}$} & 2013 & $32,633.0$ & $149,918.8$ & $182,551.8$ \\
\hline & 2014 & $30,018.8$ & $145,961.2$ & $175,980.0$ \\
\hline & 2015 & $18,574.4$ & $131,791.9$ & $150,366.3$ \\
\hline \multirow{3}{*}{$\begin{array}{l}\text { Sesudah } \\
\text { MEA }\end{array}$} & 2016 & $13,105.5$ & $132,080.8$ & $145,186.3$ \\
\hline & 2017 & $15,744.3$ & $153,083.9$ & $168,828.2$ \\
\hline & 2018 & $17,404.9$ & $162,654.3$ & $180,059.2$ \\
\hline & $\begin{array}{l}\text { Data } \\
\text { Bada }\end{array}$ & & yang D & lah dari \\
\hline
\end{tabular}

Periode sebelum MEA total ekspor di Indonesia tahun 2013 sebesar 182.551,8. Tahun 2014 menurun menjadi 175.980,0 dan tahun 2015 semakin turun di angka 150.366,3. Kemudian setelah memasuki periode MEA yaitu di tahun 2016 total ekspor masih mengalami penurunan dari tahun sebelumnya yaitu sebesar 145.186,3. Nilai total ekspor beranjak naik pada angka 168.828,2 di tahun 2017. Terakhir tahun 2018 kemarin total ekspor tercatat naik menjadi $180.059,2$.

Dari data nilai ekspor periode sebelum dan sesudah MEA yang ditunjukkan oleh tabel 1 dapat terlihat bahwa nilai ekspor mengalami penurunan mulai dari tahun 2013 sampai 2016. Kemudian mulai meningkat kembali pada tahun 2017 sampai dengan 2018. Walaupun tingkat peningkatannya masih berada dibawah angka total ekspor pada saat periode sebelum MEA. 
Dapat disimpulkan dari data pada tabel 1 bahwa diberlakukan MEA di akhir tahun 2015 tidak memberikan dampak signifikan pada peningkatan ekspor yang ada di Indonesia. Total ekspor sebelum MEA yang terjadi di Indonesia sebesar 508.898,1 sedangkan total ekspor sesudah MEA yang terjadi di Indonesia sebesar 494.073,7. Total ekspor mengalami penurunan sebesar 14.824,4 dari data sebelum adanya MEA dikurangi dengan data total ekspor sesudah MEA. Maka dapat disimpulkan bahwa diberlakukannya MEA yang diharapkan dapat meningkatkan total ekspor ternyata belum dapat memberikan peningkatan total ekspor yang terjadi di Indonesia. Justru sebaliknya bahwa total ekspor yang terjadi di Indonesia setelah diberlakukannya MEA mengalami penurunan.

Tabel 2. Data Impor di Indonesia

\begin{tabular}{|c|c|c|c|c|}
\hline \multicolumn{2}{|c|}{ Periode } & Migas & $\begin{array}{l}\text { Non } \\
\text { Migas }\end{array}$ & $\begin{array}{l}\text { Total } \\
\text { Impor }\end{array}$ \\
\hline \multirow{3}{*}{$\begin{array}{l}\text { Sebelum } \\
\text { MEA }\end{array}$} & 2013 & $45,266.4$ & $141,362.3$ & $186,628.7$ \\
\hline & 2014 & $43,459.9$ & $134,718.9$ & $178,178.8$ \\
\hline & 2015 & $24,613.2$ & $118,081.6$ & $142,694.8$ \\
\hline \multirow{3}{*}{$\begin{array}{c}\text { Sesudah } \\
\text { MEA }\end{array}$} & 2016 & $18,739.3$ & $116,913.6$ & $135,652.9$ \\
\hline & 2017 & $24,316.0$ & $132,669.5$ & $156,985.5$ \\
\hline & 2018 & $29,808.7$ & $158,816.9$ & $188,625.6$ \\
\hline
\end{tabular}

Tahun 2013 periode sebelum MEA total impor sebesar 186.628,7. Total impor mengalami penurunan menjadi 178.178,8 pada tahun 2014. Periode sebelum MEA terakhir yaitu tahun 2015 total impor menurun lagi menjadi 142.694,8. Beralih ke periode sesudah MEA tahun pertama yaitu tahun 2016 total impor masih mengalami penurunan dari tahun sebelumnya yaitu menjadi 135.652,9. Namun pada tahun kedua setelah MEA yaitu tahun 2017 total impor mengalami peningkatan menjadi 156.985,5. Disusul peningkatan terakhir di tahun 2018 total impor menjadi sebesar 188.625,6.

Tabel 2 menunjukkan bahwa total impor periode sebelum MEA yaitu tahun 2013 sampai dengan tahun pertama diadakan MEA yaitu 2016 mengalami penurunan terus menerus setiap tahunnya. Total impor mengalami peningkatan mulai tahun 2017 sampai tahun 2018. Jumlah total impor di tahun tersebut melebihi jumlah total impor yang ada pada tahun sebelum MEA.

Data yang ditunjukkan oleh tabel 2 memberikan informasi bahwa total impor yang terjadi pada periode sebelum MEA adalah sebesar 507.502,3. Sedangkan total impor pada periode sesudah MEA yaitu sebesar 481.264,0. Angka tersebut menunjukkan bahwa total impor pada periode sebelum MEA mengalami penurunan sebesar 26.238,3 apabila dikurangkan dengan total impor yang terjadi pada periode sesudah MEA. Hal ini sudah sesuai dengan harapan awal diberlakukannya MEA yaitu untuk menekan total impor yang ada di Indonesia.

Total ekspor yang terjadi di Indonesia masih lebih besar dari total impornya. Hal ini menunjukkan bahwa daya saing atau perekonomian di Indonesia cenderung baik karena tidak bergantung kepada produk luar negeri. Penurunan total ekspornyapun lebih kecil dibanding penurunan total impor yang terjadi. Dapat diartikan bahwa walaupun total ekspor di Indonesia menurun, tetapi angka penurunannya masih lebih sedikit apabila dibandingkan tingkat penurunan total impor. Total impor yang mengalami penurunan lebih besar dapat dianggap angin segar oleh pemerintah. Karena program diberlakukan MEA bisa dikatakan berhasil. 


\section{Jumlah Penduduk Miskin dan Tingkat Pengangguran}

Tabel 3. Data Jumlah Penduduk Miskin Di Indonesia

\begin{tabular}{|c|c|c|c|c|c|c|}
\hline \multirow{2}{*}{ Tahun } & \multicolumn{3}{|c|}{ Jumlah Penduduk Miskin (Juta Orang) } & \multicolumn{3}{|c|}{ Persentase Penduduk Miskin } \\
\hline & Kota & Desa & Kota+Desa & Kota & Desa & Kota+Desa \\
\hline \multicolumn{7}{|c|}{ SEBELUM MEA } \\
\hline September 2013 & 10.63 & 17.92 & 28.55 & 8.52 & 14.42 & 11.47 \\
\hline September 2014 & 10.36 & 17.37 & 27.73 & 8.16 & 13.76 & 10.96 \\
\hline September 2015 & 10.62 & 17.89 & 28.51 & 8.22 & 14.09 & 11.16 \\
\hline \multicolumn{7}{|c|}{ SESUDAH MEA } \\
\hline September 2016 & 10.49 & 17.28 & 27.77 & 7.73 & 13.96 & 10.85 \\
\hline September 2017 & 10.27 & 16.31 & 26.58 & 7.26 & 13.47 & 10.37 \\
\hline Maret 2018 & 10.14 & 15.81 & 25.95 & 7.02 & 13.20 & 10.11 \\
\hline
\end{tabular}

Sumber : Data Sekunder yang Diolah dari Badan Pusat Statistik

Tabel 3 menunjukkan data jumlah penduduk miskin yang terdapat di kota, di desa dan total dari jumlah penduduk miskin yang adan di kota dan di desa. Jumlah tersebut dinyatakan dalam satuan Juta Orang. Data diambil dari website BPS yang menunjukkan 3 tahun sebelum penerapan MEA yaitu dari tahun 20132015 dan periode 3 tahun setelah penerapan MEA yaitu tahun 2016-2018.

Dari tabel 3 dapat diketahui bahwa tahun 2013 jumlah penduduk miskin yang ada di kota sebanyak 10.63 juta orang. Jumlah penduduk miskin yang ada di desa sebanyak 17.92 juta orang. Sehingga total jumlah penduduk miskin di tahun 2013 sebanyak 28.55 juta orang. Kemudian di tahun 2014 jumlah penduduk miskin mengalami penurunan baik di kota maupun di desa. Jumlah penduduk miskin di kota sebanyak 10.36 juta orang sedangkan di desa sebanyak 17.37 juta orang. Total jumlah penduduk miskin tahun 2014 menjadi sebanyak 27.73 juta orang. Namun pada tahun berikutnya yaitu tahun 2015 jumlah penduduk miskin mengalami kenaikan di kota menjadi 10.62 juta orang dan di desa menjadi 17.89 juta orang. Sehingga total penduduk miskin di tahun 2015 sebanyak 28.51 juta orang.

Periode sesudah MEA yaitu tahun 2016 jumlah penduduk miskin kembali mengalami penurunan. Jumlah penduduk miskin di kota menjadi sebanyak 10.49 juta orang dan di desa menjadi sebanyak 17.28 juta orang. Total penduduk miskin tahun 2016 yaitu sebanyak 27.77 juta orang. Selanjutnya di tahun 2017 jumlah penduduk miskin di kota sebanyak 10.27 juta orang dan di desa sebanyak 16.31 juta orang. Angka ini juga menurun dari tahun sebelumnya sehingga total jumlah penduduk miskin di tahun 2017 menjadi sebanyak 26.58 juta orang. Penurunan masih terus berlanjut hingga di tahun 2018 jumlah penduduk miskin di kota menjadi sebanyak 10.14 juta orang dan di desa menjadi sebanyak 15.81 juta orang. Total penduduk miskin di tahun 2018 menjadi sebanyak 25.95 juta orang.

Maka dapat disimpulkan bahwa tingkat kemiskinan yang diukur dari total jumlah penduduk miskin baik yang ada di kota maupun di desa mengalami penurunan secara terus menerus selama diberlakukannya MEA di Indonesia. Jumlah terakhir di tahun 2018 bahkan jumlah yang paling sedikit selama 10 
tahun terakhir. Hal ini merupakan kabar baik bagi pemerintah karena telah berhasil menurunkan jumlah penduduk miskin setiap tahun. Yang berarti upaya dalam memberantas kemiskinan dengan berbagai macam upaya salah satunya dengan diberlakukan MEA sudah membuahkan hasil yang memuaskan.

Tabel 4. Data Tingkat Pengangguran di Indonesia

Tahun Februari Agustus

\begin{tabular}{ccc}
\multicolumn{3}{c}{ Sebelum MEA } \\
\hline 2013 & 5.88 & 6.17 \\
2014 & 5.70 & 5.94 \\
2015 & 5.81 & 6.18 \\
\hline \multicolumn{3}{c}{ Sesudah MEA } \\
\hline 2016 & 5.50 & 5.61 \\
2017 & 5.33 & 5.50 \\
2018 & 5.13 & 5.34
\end{tabular}

Sumber: Data Sekunder yang Diolah dari Survei Angkatan Kerja Nasional (Sakernas)

Tabel 4 menunjukkan perkembangan data tingkat pengangguran yang ada di Indonesia dari tahun 2013-2018. Data tersebut dinyatakan dalam satuan persen. Data yang didapatkan yaitu data tahunan yang terdiri dari dari 2 bulan yaitu bulan Februari dan Agustus.

Tahun 2013 tingkat pengangguran di bulan Februari sebesar $5.88 \%$ dan di bulan Agustus meningkat menjadi $6.17 \%$. Tahun berikutnya yaitu tahun 2014 tingkat pengangguran mengalami penurunan menjadi $5.70 \%$ di bulan Februari dan meningkat kembali di bulan Agustus menjadi sebesar 5.94\%. Tahun 2015 yaitu periode terakhir sebelum penerapan MEA tingkat pengangguran kembali mengalami penurunan sehingga menjadi sebesar $5.81 \%$ di bulan Februari tetapi mengalami peningkatan kembali di bulan Agustus menjadi sebesar 6.18\%.

Periode setelah penerapan MEA yaitu tahun 2016 di bulan Februari tingkat pengangguran menurun menjadi sebesar $5.50 \%$ dan di bulan Agustus meningkat lagi menjadi sebesar $5.61 \%$. Tahun berikutnya yaitu tahun 2017 di bulan Februari tingkat pengangguran turun di angka $5.33 \%$ dan naik kembali menjadi 5.50\% di bulan Agustus. Tahun terakhir setelah penerapan MEA yaitu tahun 2018 tingkat pengangguran kembali mengalami penurunan menjadi sebesar 5.13\% di bulan Februari namun meningkat kembali menjadi sebesar 5.34\% di bulan Agustus.

Dari tabel 4 dapat disimpulkan bahwa tingkat pengangguran pada periode sebelum penerapan MEA cenderung belum stabil karena sempat mengalami penurunan namun tahun berikutnya kembali mengalami peningkatan dalam prosentasenya. Sedangkan tingkat pengangguran pada periode sesudah MEA dapat dilihat dalam tabel 4 yaitu selalu mengalami penurunan secara terus menerus setiap tahunnya. Tingkat penurunannyapun dapat dikatan signifikan dilihat dari perbandingan tahun-tahun sebelumnya. Dengan demikian dapat disimpulkan bahwa penerapan MEA akhir tahun 2015 membawa dampak baik bagi tingkat pengangguran yang ada di Indonesia. Dilihat dari data tahun 20162018 tingkat pengangguran yang ada di Indonesia mengalami penurunan yang signifikan.

\section{Pendapatan per Kapita dan Produk Domestik Bruto}

Tabel 5. Data Pendapatan Nasional Per Kapita di Indonesia

\begin{tabular}{cc|} 
Tahun & $\begin{array}{c}\text { Pendapatan Nasional per Kapita } \\
\text { Sebelum MEA }\end{array}$ \\
\hline 2013 & $28,890,818.2$ \\
2014 & $31,376,037.4$ \\
2015 & $32,958,302.6$ \\
\hline \multicolumn{2}{c}{ Sesudah MEA } \\
\hline 2016 & $36,466,355.0$ \\
2017 & $38,375,519.6$ \\
\hline
\end{tabular}

Sumber: Data Sekunder yang Diolah dari Badan Pusat Statistik 
Pendapatan nasional perkapita adalah angka yang didapatkan dari pendapatan nasional di Indonesia pada suatu periode tertentu dibagi dengan jumlah penduduknya. Tabel 5 memberikan informasi berupa data pendapatan nasional per kapita di Indonesia pada periode sebelum MEA yaitu tahun 20132015 dan periode sesudah MEA yaitu pada tahun 2016-2017. Data untuk tahun 2018 tidak dapat ditampilkan dikarenakan data tahun tersebut belum dipublikasikan sampai saat ini.

Tabel 5 menunjukkan bahwa pada tahun 2013 pendapatan nasional per kapita sebesar 28.890.818,2. Kemudian di tahun 2014 pendapatan nasional per kapita mengalami kenaikan sebesar 2.485.219,2 menjadi sebesar 31.376.037,4. Peningkatan masih terus terjadi sampai di akhir periode sebelum penerapan MEA yaitu di tahun 2015 pendapatan nasional per kapita naik sebesar 1.582.265,2 sehingga berada di angka 32.958.302,6. Selama tiga tahun berturut-turut pendapatan nasional per kapita mengalami peningkatan.

Periode sesudah MEA yaitu dimulai pada tahun 2016 pendapatan nasional per kapita di Indonesia masih terus bertambah sebesar 3.508.052,4 sehingga totalnya menjadi sebesar 36.466.355,0. Terakhir pada tahun 2017 peningkatan pendapatan nasional per kapita sebesar 1.909.164,6 sehingga berada di angka 38.375.519,6. Pendapatan per kapita masih mengalami peningkatan pada saat periode MEA sudah diterapkan di Indonesia.

Dari data yang telah dijelaskan diatas dapat disimpulkan bahwa pendapatan nasional per kapita sudah mulai meningkat bahkan sebelum adanya penerapan MEA di Indonesia sebesar 4.067.484,4. Setelah diberlakukan MEA pendapatan nasional per kapita tetap mengalami peningkatan yiatu sebesar 5.417.217,0. Peningkatan yang terjadi pada saat penerapan MEA lebih besar daripada pada saat periode sebelum MEA. Sehingga dapat dikatakan bahwa harapan penerapan MEA dapat meningkatkan kesejahteraan rakyat sudah berhasil. Dilihat dari data yang menunjukkan bagaimana pendapatan nasional per kapita meningkat lebih besar dibandingkan pada saat periode sebelum penerapan MEA.

Tabel 6. Data Produk Domestik Bruto Per Kapita di Indonesia

\begin{tabular}{ccc}
\hline Tahun & PDB per Kapita \\
\hline 2013 & Sebelum MEA \\
2014 & $38,365,914.7$ \\
2015 & $41,915,863.4$ \\
\hline \multicolumn{4}{c}{ Sesudah MEA } \\
\hline 2016 & $47,957,225.8$ \\
2017 & $51,887,250.6$ & \\
Sumber : Data & Sekunder yang Diolah dari \\
Badan Pusat Statistik &
\end{tabular}

Produk domestik bruto per kapita adalah angka yang dihasilkan dari produk domestik bruto nasional dibagi dengan jumlah penduduk yang ada di Indonesia. Data yang ditunjukkan oleh tabel 6 merupakan data PDB per kapita periode sebelum diterapkan MEA yaitu dari tahun 2013-2015 dan sesudah diterapkan MEA yaitu tahun 2016-2017. PDB per kapita tahun 2018 tidak dapat dimasukkan ke dalam tabel karena data tersebut belum dipublikasikan oleh BPS sama halnya dengan data pendapatan nasional per kapita.

Tahun pertama periode sebelum penerapan MEA yaitu tahun 2013 diketahui bahwa PDB per kapita di Indonesia sebesar 38.365.914,7. Kemudian mengalami kenaikan di tahun berikutnya yaitu tahun 2014 sebesar 3.549.948,7 sehingga PDB per kapita tahun 2014 menjadi sebesar 41.915.863,4. Selanjutnya pada tahun 2015 PDB per kapita masih mengalami 
kenaikan yaitu sebesar 3.203.748,7 sehingga menjadi sebesar 45.119.612,1. Selama 3 tahun berturut-turut PDB per kapita mengalami kenaikan di Indonesia.

Periode sesudah MEA yaitu mulai tahun 2016 PDB per kapita di Indonesia tercatat sebesar 47.957.225,8 yaitu meningkat sebesar 2.837.613,7 dari tahun sebelumnya. Peningkatan juga masih terjadi di tahun 2017 PDB per kapita meningkat sebesar 3.930.024,8 sehingga total PDB per kapita tahun 2017 menjadi sebesar 51.887.250,6.

Dari data yang telah dijelaskan diatas dapat diketahui bahwa PDB per kapita mengalami peningkatan dari tahun ke tahun baik sebelum penerapan MEA maupun sesudah penerapan MEA. Total peningkatan PDB perkapita pada periode sebelum penerapan MEA adalah sebesar 6.753.697,4 sedangkan peningkatan PDB per kapita pada periode sesudah penerapan MEA adalah ssbesar 6.767.638,5. Sehingga dapat disimpulkan bahwa peningkatan PDB per kapita pada periode sesudah MEA lebih besar daripada peningkatan PDB per kapita pada periode sebelum MEA. Dengan kata lain harapan penerapan MEA dapat meningkatkan total PDB per kapita di Indonesia sudah berhasil dicapai walaupun jumlahnya masih tidak terlalu banyak.

\section{E. KESIMPULAN}

Penerapan MEA selama tiga tahun di Indonesia belum dapat diketahui hasilnya. Untuk mengetahui keberhasilan penerapan MEA diambil data-data dari beberapa indikator seperti tingkat ekspor impor, jumlah penduduk miskin dan tingkat pengangguran, yang terakhir dengan melihat peningkatan pendapatan nasional perkapita dan produk bruto perkapita.

Total ekspor sebelum MEA yang terjadi di Indonesia sebesar 508.898,1 sedangkan total ekspor sesudah MEA yang terjadi di Indonesia sebesar 494.073,7. Total ekspor mengalami penurunan sebesar 14.824,4 dari data ekpor sebelum adanya MEA. Maka dapat disimpulkan bahwa diberlakukannya MEA ternyata belum dapat memberikan peningkatan total ekspor yang terjadi di Indonesia. Total impor yang terjadi pada periode sebelum MEA adalah sebesar 507.502,3. Sedangkan total impor pada periode sesudah MEA yaitu sebesar 481.264,0. Angka tersebut menunjukkan bahwa total impor mengalami penurunan sebesar 26.238,3 pada periode sesudah MEA. Hal ini sudah sesuai dengan harapan awal diberlakukannya MEA yaitu untuk menekan total impor yang ada di Indonesia.

Upaya penerapan MEA dalam memberantas kemiskinan sudah membuah hasil yang positif. Hal ini dapat dilihat dari total jumlah penduduk miskin baik yang ada di kota maupun di desa mengalami penurunan secara terus menerus selama diberlakukannya MEA. Jumlah terakhir di tahun 2018 bahkan jumlah yang paling sedikit selama 10 tahun terakhir. Tingkat pengangguran pada periode sesudah MEA mengalami penurunan secara terus menerus setiap tahunnya. Dengan demikian dapat disimpulkan bahwa penerapan MEA membawa dampak baik bagi penurunan tingkat pengangguran yang ada di Indonesia.

Pendapatan nasional per kapita sebelum adanya penerapan MEA sebesar 4.067.484,4. Setelah diberlakukan MEA pendapatan nasional per kapita yaitu sebesar 5.417.217,0. Sehingga keberhasilan penerapan MEA dalam meningkatkan pendapatan nasional per kapita dapat dikatakan berhasil. Total peningkatan PDB perkapita pada periode sebelum penerapan MEA sebesar 6.753.697,4 sedangkan peningkatan PDB per kapita pada periode sesudah penerapan MEA sebesar 6.767.638,5. 
Sehingga dapat disimpulkan bahwa peningkatan PDB per kapita pada periode sesudah MEA lebih besar daripada peningkatan PDB per kapita pada periode sebelum MEA. Dengan kata lain harapan penerapan MEA dapat meningkatkan total PDB per kapita di Indonesia sudah berhasil dicapai walaupun jumlahnya masih tidak terlalu banyak.

Penelitian selanjutnya diharapkan memasukkan faktor-faktor lain yang berkaitan dengan peningkatan perekonomian. Karena perekonomian berkembang dengan berbagai faktor yang belum dijelaskan di penelitian ini.

\section{DAFTAR PUSTAKA}

Abdurofiq, Atep. 2014. Menakar Pengaruh Masyarakat Ekonomi ASEAN 2015 Terhadap Pembangunan Indonesia. Salam; Jurnal Filsafat dan Budaya Hukum. November 2014.

Apriliana, Tria. 2016. Posisi Ekspor Impor Indonesia dalam MEA (Sebuah Studi Komparatif). Prosiding Seminar Nasional "Dinamika Global : Rebranding Keunggulan Kompetitif Berbasis Kearifan Lokal. ISBN 978-602-60569-2-44.

Avianti, I. 2015. Peluang dan Tantangan Akuntan di Era MEA. Simposium Nasional Akuntansi (SNA) XVIII, Medan.

Congge, Umar. 2015. Masyarakat Ekonomi ASEAN (MEA) Harapan dan Tantangan dalam Perekonomian Bangsa. Seminar Nasional "Revolusi Mental dan Kemandirian Bangsa Melalui Pendidikan Ilmu-ilmu Sosial dalam Menghadapi MEA 2015. Makassar, 28-29 Nopember 2015.

Firdaus, Ahmad Yarist dan Hakim, Muhammad Andi. 2013. Penerapan "Acceleration To Improve The Quality Of Human Resources" dengan Pengetahuan, Pengembangan dan Persaingan sebagai Langkah dalam Mengoptimalkan Daya Saing Indonesia di MEA 2015. Economics Development Analysis Journal. Vol. 2 No. 2 Mei 2013.

Hidayah, Farida Nur dan Roisah, Kholis. 2017. Analisis Dampak Kebijakan Pemerintah Indonesia Terhadap Persaingan Perdagangan Jasa Di Bidang Konstruksi Dalam Rangka Masyarakat Ekonomi ASEAN. Jurnal Law Reform. Vol. 13 No.1 Tahun 2017.

Iskamto, Dedi. 2016. Industri Keuangan Bank Syariah Nasional dalam Masyarakat Ekonomi ASEAN. Jurnal Ekonomi dan Bisnis Islam (JEBI). Vol.1 No.1 JanuariJuni 2016.

Munthe, Salman. 2015. Strategi Implementasi Sistem Ekonomi Islam Dalam Menghadapi Masyarakat Ekonomi ASEAN (MEA). Jurnal Perspektif Ekonomi Darussalam. Vol.1 Nomor 2 September 2015. ISSN. 2502-6976.

Naukoko, Princilvanno A. 2017. Profesi Akuntan Di Era Masyarakat Ekonomi Asean (MEA). Journal of ASEAN Studies on Maritime Issues. Vol. 3 No. 4 May 2017.

Pratiwi, Erliz Nindi dan Mahmudah, Rifa Atun. 2013. Peningkatan Daya Saing Tenaga Kerja Indonesia Melalui Korelasi Input Penunjang Tenaga Kerja dalam Menghadapi MEA 2015. Economics Development Analysis Journal. Vol.2 No. 2 Mei 2013. 
Pratiwi, Mutiara dan Daulay, Dr. Murni. 2014. Pengaruh MEA 2015 Terhadap Integrasi Pada Sistem Perdagangan Di Indonesia. Jurnal Ekonomi dan Keuangan. Vol.3 No.4.

Suryandani, Atika. 2018. Pengaruh Pertumbuhan Perusahaan, Ukuran Perusahaan, dan Keputusan Investasi terhadap Nilai Perusahaan pada Perusahaan Sektor Property dan Real Estate. Bussines Management Analysis Journal (BMAJ). Vol. 1 No. 1 Oktober 2018.

Syaifullah, Ahmad dan Malik, Nazaruddin. 2017. Pengaruh Indeks Pembangunan Manusia dan Produk Domestik Bruto terhadap Tingkat Kemiskinan di ASEAN-4. Jurnal Ilmu Ekonomi. Vol. 1 Jilid 1/2017 Hal. 107-119.

www.bps.go.id. Publikasi Perkembangan Ekspor dan Impor Indonesia Juni 2018. Diakses tanggal : 30 Januari 2019.

www.bps.go.id. Publikasi Keadaan Ketenagakerjaan Indonesia Februari 2018. Diakses tanggal : 30 Januari 2019

www.bps.go.id. Publikasi Profil Kemiskinan di Indonesia Maret 2018. Diakses tanggal : 30 Januari 2019

www.bps.go.id. Katalog BPS 9301001. Pendapatan Nasional Indonesia 2013-2017. Diakses tanggal : 30 Januari 2019

www.bps.go.id. Katalog BPS 9301003. Produk Domestik Bruto Indonesia Triwulanan 2013-2017. Diakses tanggal : 30 Januari 2019

www.bps.go.id. Katalog BPS 9301003. Produk Domestik Bruto Indonesia Triwulanan 2014-2018. Diakses tanggal : 30 Januari 2019

www.bps.go.id. Katalog BPS 9301005. Produk Domestik Bruto Indonesia Menurut Pengeluaran 2013-2017. Diakses tanggal : 30 Januari 2019 